UDC 338.24.01

DOI: $10.15587 / 2312-8372.2016 .81469$

Bidnjak M., Kompanets $\mathbf{K}$.

\title{
STABILITY STUDY OF ORGANIZATIONAL MANAGEMENT STRUCTURES
}

Проведено аналіз побудови сучасних типів організащійних структур управління. Доведено, що на сучасному етапі рішення для розвитку підприємств за допомогою математичних моделей формування організаційних структур є найбільш ефективним і раціональним. Розглянуто та проаналізовано модель Р. Норманна.

Ключові слова: організаційні структури управління, моделі, моделювання, адаптивний підхід.

\section{Introduction}

The current economic situation in Ukraine and the rapid globalization crisis lead to permanent adaptation of companies to it. Structuredness and systematicity are necessary for the maintenance in these conditions now. Formation of a new organization and production structure is the basis of both the integrity and organization systems. Historically outdated principles and methods of formation of new organizational structures need to adapt to modern conditions. Therefore, to determine the efficiency of organizational and economic systems we must use mathematical models, which will allow to define strategic directions of development for managers.

\section{The object of research and its technological audit}

The object of research is the process of optimizing organizational management structures on the example of R. Norman model.

Speaking simply, organizational structure is device model of any company listing all departments and mandatory indication of accountability for each of them. This model is designed to provide an understanding of the logic of the organization activity and how its constituent components interact with each other. It can also say that the organizational structure determines all the formal relationships within any company and essentially captures the identity of specific tasks within the competence of the department. Gill Corkindale, a successful writer and business trainer, in one of his articles, notes that «fuzzy, poor organizational structure leads to contradictions; people confuse their responsibilities and roles, management decisions are made slowly and all this creates a context in which the achievement of results is complicated by useless stress and conflict» [1].

\section{The aim and objectives of research}

The aim of research is fundamental study of organizational structures using a comprehensive analysis of existing management systems and simulation modeling.

To achieve this aim, the following scientific tasks are defined:

1. Conduct a comprehensive analysis of the formation of organizational management structures.
2. Analyze the practicality of R. Norman model.

3. Form the basic elements of the organization philosophy.

4. Establish existing basic functions that may be lie in the R. Norman model.

\section{Literature review}

Today, there are many works in scientific literature about the principles, problems and types of organizational management structures. In [1] the basic elements and principles of organizational structures are given. The author of [2] presents a holistic concept of design and modeling organizational structure with the current economic, managerial and information tools and technologies. Problems of modeling organizational structure and their problems of its design are given in [3]. They highlighted a modeling method, which is in optimization of the production structure. The author of [4] proposes modeling of the process structure based on the principles of flexibility and adaptation. In the book [5] the author describes not only the possible design of organizational structures, and stops at the context and rules of their formation. «Generalized design rules that can be used to develop design of organizational structures are accompanied by specific goals of the company» [6]. Author of [7] notes that the use of divisional company structure on the second hierarchy level is divided into organizational units (segments, divisions) with a high level of autonomy, which are formed by grouping tasks by grouping products, markets, customers, etc. So, he is separating all components of organizational structures. In [8] the author describes the nature of organizational structures and its role in the management of personnel. He is noted in his book «Metaphor organizations» that the organization as a machine, body, brain, culture, political system, psychiatric prison, process of change. The author of [9] notes that the integrity of the organizational structure depends on corporate bonds, common goals. The ideal structure of its interpretation should be based on the internal rules of the company and at the same time respond to external changes. In the book [10] the author shows an influence of organizational structures on microclimate in the organization. Modification transformations in the structure of the company are represented, learning experience of foreign countries.

But these works aren't fully includes the effect of organizational structure on the development of companies in the 
current economic conditions. Therefore, the need for use of modified methods of their formation is directly precondition for efficient operation of companies.

\section{Materials and methods of research}

The main methods of research are: comparative and descriptive, system and structural, simulation modeling - creation of algorithms of optimal organizational structures, mathematical modeling - to conduct experimental research; abstract and logical method - to make theoretical and methodological generalizations and drawing conclusions.

\section{Research results}

Under the organizational structure we mean any artificial entity with aim of realization of the objectives, which has its mission and created to achieve the goals. There are many examples of our ideas. There are production entities and their structural divisions, government agencies, various groups of NGOs, institutions and so on. So, if there is a goal and should begin the path to achieve it, organizational structure is usually created under the legal framework to achieve this goal. Formal organizational structure can be presented as follows (Fig. 1).

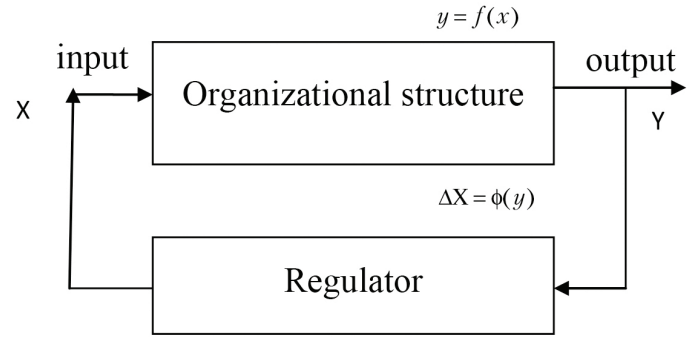

Fig. 1. The operation scheme of organizational structure

As shown in the present scheme, organizational structure operates depending on its mission and its goals.

Present model of organizational structure is statistical. It is no reflection of individual elements or components of this structure, there are no relationships, structure of elements, variables that characterize the change of state of organizational structure in time. This is the most common model of organizational structure. But in the real conditions, organizational structures have structure of elements that implement the specified functions, the relationship between the elements that change their status under the influence of the environment, making them dynamic open systems.

One of the first, who tried to create a functional model, though on the example of service company, was Richard Norman in his book «Service management» [5], but it was presented in a static form. R. Norman model includes five components (Fig. 2).

Content definition of block of the model is as follows.

Market segment is closely linked to the norms and rules of operation. This is a special category of consumers. All service organization is set for them. Norms and rules of organization operation are developed depending on this.

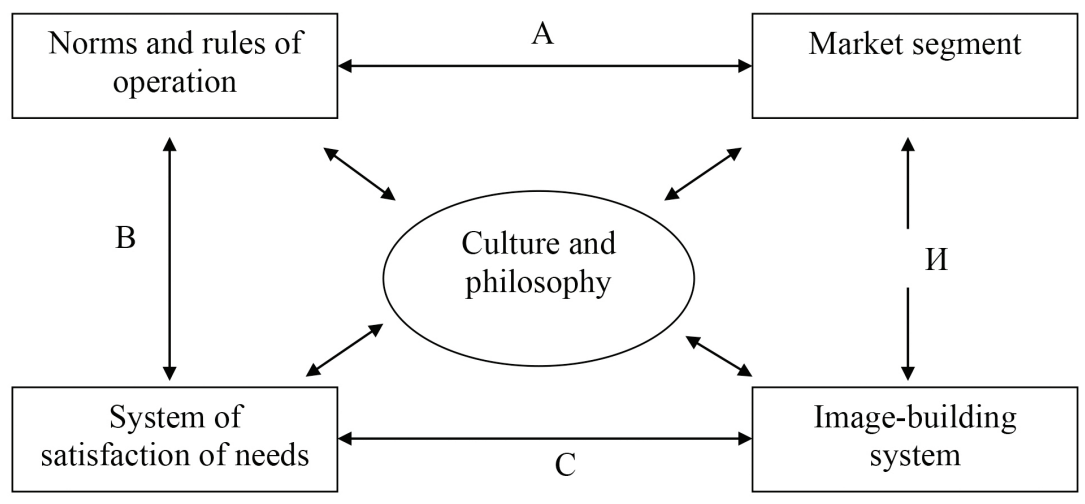

Fig. 2. The scheme of R. Norman model

The system of customer satisfaction is based on the concept of service, which is all that brings consumer satisfaction. The concept of service in the R. Norman model covers too complex combinations of values. There are sometimes impossible to analyze. Some of them have a material basis, and some relate to the field of psychology and emotions. From this it should be noted that some value to the customer is the key, and the rest are minor. Depending on the mission of organizational structure, a system of priorities is formed, and therefore, a system of services for consumers is formed.

The system of customer satisfaction consists of three components:

Firstly, it is personnel of organization. They determined the quality and quantity of services. In modern organizational structures is a constant search for certain methods of client relations. They must constantly seek new ways of mobilizing workers to perform their work efficiently.

Secondly, consumers who play a vital role in the service organization as they not only get the service, but also included in the operation. Therefore, consumers need to encourage quality service as well as their employees.

Thirdly, technology and financial support of services, in addition to high complexity, can differ by the high technological and capital intensity. It should be noted that modern technology, especially information, will play a greater and greater role and operation of organizational structures of service technology along with physical characteristics play an important role in social interaction of consumers' workforce and service providers.

Image-building system is considered as a management tool, and the image as the information that management uses to influence on the workers and consumers. The perception of the organization image and prospects of its development significantly affect its position on the market and cost efficiency. In the long run it depends on what it provides and who its customer.

Culture and philosophy of the organization is very important in terms of monitoring, support and development of social processes that are included in the scope of services that bring social benefits.

In general, it should have in mind that the culture and philosophy of organization performs an integrated function and is an important factor in the efficiency of organizational structures.

Based on this, with some convention in R. Norman model, we can submit it (model) in the system of available predefined functions. 


$$
\begin{aligned}
& A=f_{1}\left(x_{1}, x_{2}, \ldots x_{n}\right), \\
& B=f_{2}[A(\bar{X}), p], \\
& C=f_{3}(B, N), \\
& U=\min \left(C-Z_{0}\right), \\
& Y(t)=f_{4}(A, B, C, U, t),
\end{aligned}
$$

where $A-$ multifactor function of demand for services, which fully depends on the $X_{1}, X_{2}, \ldots X_{n} ; B$ - function, which represents the effect of service in accordance with accepted norms and rules of service, depending on the demand and system priorities of $P\left(P=\left(\phi_{1}, \phi_{2}, \ldots \phi_{p}\right) ; C-\right.$ function, which represents the volume of service performance, depending on the resource potential $N ; U-$ function, which characterizes the deviation $C$ from the desired standard $Z ; Y(t)$ - effectiveness of the adopted operation strategy of organization that takes into account not only the arguments $A, B, C, U$, but the time t.

If we consider the block of $\mathrm{R}$. Norman model with the problems in the operation of organizational structures, they can be formed as follows.

Block of the market segment. Major problems associated with forecasting and formation of demand for the service and needs analysis and market segmentation.

Block of the norms and regulations of the service rules. Problems are related to the justification of the priorities and development of the model of integrated facilities of service implementation.

Block of the customer satisfaction. Problems are primarily technology service, training and recruitment, improvement of services and work with customers to ensure profitability of the operation.

Block of the image-building. It is characterized by problems of a structure and management organization to ensure the goal.

Block of culture and philosophy highlights the problems of strategic management. This is development of mission, new objectives, concepts of possible development strategies, implementation of social functions.

\section{SWOT-analysis of research results}

Strength of the conducted research is an optimization of organizational management structures that allows to adapt companies to modern conditions covering certain market segments, taking into account the system of customer satisfaction and image-building.

Weakness is that this model of organizational structure is quite complicated, as consisting of a number of factors that characterize internal and external environment of the company, some of which have difficulty of accurately determination.

Opportunities for further research are adopting the experience of foreign countries for modification of organizational structures in terms of globalization, which makes it possible to identify, explore and create new factors not taken into account earlier.

Threats to research results is that globalization processes in Ukraine are very variable and affect the company both positive and negative, and this leads to difficulty monitoring and detection parameters that are necessary to create optimal model of organizational structure.

\section{Conclusions}

1. Complex analysis of formation of organizational management structures is conducted in the article. However, it is shown that in the work of scientists and practice in the operation of companies is not fully take into account the impact of organizational structures, such as their role in modern globalization for development of enterprises. Therefore, it was proved that the organizational structure is statistical. They have no description of certain elements or components of this structure, there are no relationships of elements, structure of variables that characterize the change of state of organizational structure in time.

2. For achieving the aim, practicality of using R. Norman model is analyzed. It is proved that the concept of services in R. Norman model covers too complex combinations of values that are sometimes impossible to analyze. Some of them have a material basis, and some relate to the field of psychology and emotions. From this it should be noted that some value to the customer is the key, and the rest are minor. Depending on the mission of organizational structure, a system of priorities and therefore, a system of services for consumers are formed.

3. The main elements of the organization philosophy are formed. It makes it possible to form the conclusion that the culture and philosophy of organization perform integrated function and is an important factor in the efficiency of organizational structures.

4. Above mentioned tasks led to establish the major existing features that may be lying in R. Norman model.

Without detailed analysis of R. Norman model it should be noted that it is quite difficult especially in the formalization of components and does not cover all problems arising in the operation of organizational structures. The most complex and unsolved issues include: choice of norms and rules of service especially for non-industrial nature; determine the most effective organization $\mathrm{Z}_{0}$ and ways to achieve it; evaluation of the efficiency of the organizational structure and evaluation of culture and philosophy elements of business and economic activities as well as the factors that significantly affect the efficiency of the organization.

As follows from the methodology of research of operation efficiency and development of organizational structures, simulation method is the most appropriate and gives good practical results.

\section{References}

1. Organizatsionnaia struktura: osnovnye elementy i printsipy postroeniia [Electronic resource] // LPgenerator. - Available at: \www/URL: http://lpgenerator.ru/blog/2015/09/21/ organizacionnaya-struktura-osnovnye-elementy-i-principypostroeniya/\#ixzz4MP57FRtw

2. Boiko, B. V. Modeliuvannia orhanizatsiinykh struktur silskohospodarskykh pidpryiemstv [Text] / B. V. Boiko // Naukovi chytannia. - 2013. - Vol. 2. - P. 198-202.

3. Kovalenko, O. Problems of modeling organizational structures [Electronic resource] / O. Kovalenko, T. Klopotiy // Efektyvna ekonomika. - 2010. - № 10. - Available at: \www/ URL: http://www.economy.nayka.com.ua/?op=1\&z=233

4. Bilei-Ruban, N. V. Modeliuvannia vyrobnytstv shveinoi haluzi iz vykorystanniam ikonohrafichnykh modelei [Text] / N. V. BileiRuban // Visnyk KNUTD. - 2013. - № 1 (69). - P. 15-22. 
5. Norman, R. Service Management [Text] / R. Norman, C. Haksever. - Gardners Books, 1989. - 267 p.

6. Baligh, H. H. Organization Structures: Theory and Design, Analysis and Prescription. Information and Organization Design Series [Text] / H. H. Baligh. - Springer, 2006. - 305 p. doi:10.1007/0-387-28317-x

7. Nalepka, A. Struktura organizacyjna [Text] / A. Nalepka. Kraków: Antykwa, 2001. - 91 p.

8. Morgan, G. Organisatsiooni metafoorid [Text] / G. Morgan. Tallinn: Äripäeva Kirjastus, 2008. - 527 p.

9. Siimon, A. Organisatsioon ja organisatsioonikultuur [Text] / A. Siimon, M. Vadi. - Tartu: Tartu Ülikooli Kirjastus, 1999. $269 \mathrm{p}$.

10. Kanter, R. M. The Change Masters: Innovation for Productivity in the American Corporation [Text] / R. M. Kanter. - New York: Simon \& Schuster, 1983. - 436 p.

\section{ИССЛЕДОВАНИЕ УСТОЙЧИВОСТИ ОРГАНИЗАЦИОННЫХ СТРУКТУР УЛРАВЛЕНИЯ}

Проведен анализ построения современных типов организационных структур управления. Доказано, что на современном этапе решение для развития предприятий с помощью математических моделей формирования организационных структур является наиболее эффективны и рациональным. Рассмотрена и проанализирована модель Р. Норманна.

Ключевые слова: организационные структуры управления, модели, имитационное моделирование, адаптивный подход.

Бідняк Михайло Несторович, доктор технічних наук, професор, завідувач кафедри менеджменту, Національний транспортний університет, Київ, Україна.

Компанець Катерина Андріївна, кандидат економічних наук, доцент, кафедра менеджменту, Національний транспортний університет, Київ, Україна, e-mail: ket13@ukr.net.

Бедняк Михаил Нестерович, доктор технических наук, профессор, заведующий кафедрой менеджмента, Национальный транспортный университет, Киев, Украина.

Компанеи, Екатерина Андреевна, кандидат экономических наук, доцент, кафедра менеджмента, Национальный транспортный университет, Киев, Украина.

Bidnjak Michael, National Transport University, Kyiv, Ukraine. Kompanets Katarina, National Transport University, Kyiv, Ukraine, e-mail: ket13@ukr.net

Кононова О. Е. ДОСЛІЖЕННЯ ЕТАПІВ ЕВОЛЮЦї
ТА ШКІЛ СТРАТЕГІЧНОО УПРАВЛІНН

Проведено аналіз літературних джерел та розглянуто зміст та сутність основоположних шкіл стратегічного управління, таких як школа дизайну, школа планування, школа позиціонування, школа підприємництва, когнітивна школа, школа навчання, школа влади, школа культури, школа зовнішнього середовища, школа конфігуращії. Результати проведеного дослідження еволющіі підходів стратегічного управління систематизовано і представлено в таблиці.

Ключові слова: стратегія, стратегічне управління, еволюція, підходи, школи, школа дизайну, школа планування, школа позиціонування.

\section{1. Ветуп}

У своєму розвитку стратегічне управління вже встигло пройти довгий шлях. Багато популярних колись методів заперечувалися новими поколіннями бізнесменів i на зміну ім приходили ще більш вдосконалені.

Поява нових наукових теорій та розроблених на іх основі методів стратегічного управління завжди носило прикладний характер та було направлено на рішення проблем, з якими стикалося підприємство в поточній діяльності. Змінювалися умови, в яких функціонували підприємства, змінювалися і самі підприємства. Кожне нове поєднання внутрішніх та зовнішніх умов народжувало нові питання, на які дослідники намагалися знайти адекватні відповіді.

У підсумку, зараз існує велика кількість різних гіпотез, формулювань і концепцій щодо ролі і місця стратегії в управлінні підприємством. Знання про чужі помилки і успіх озброює важливою перевагою: розумінням адекватності тих чи інших стратегічних інструментів.

\section{2. Об'ект дослідження та його технологічний аудит}

3 метою визначення та узагальнення основних етапів еволюції та відповідних їм шкіл стратегічного управління було проведено аналіз сучасної наукової літератури. Елементи стратегічного управління були описані ще в перших наукових працях з управління підприємством [1], а запровадження стратегічного підходу до управління підприємствами почалося в першій половині XX ст. $\mathrm{У}$ цей період домінувало довгострокове планування та стратегічний підхід до управління підприємством використовувався не системно. Автор [2] зазначає, що суттєві зміни у зовнішньому середовищі спонукали підприємства звичайно із запізненням звертати увагу на необхідність зміни стратегії. Після того, як переорієнтація підприємства завершувалася, у центрі уваги керівництва знову виникали оперативні питання використання потенціалу нової стратегічної позиції, і так доти, поки в середовищі знову не відбувалися значні змін. Тому було піддано сумніву доцільність використання методів довгострокового планування і в 1965 р. запропоновано модель стратегічного планування, яке передбачало постійну переоцінку і переробку початково розроблених концепцій розвитку підприємства з урахуванням зовнішніх «сигналів». У 70 -х роках [2] запропонований термін «стратегічне управління».

Неузгодженість авторів щодо ознак систематизації шкіл стратегій, а також поява нових концепцій стратегічного управління потребують перегляду існуючих підходів до методології стратегічного управління. В умо- 